\title{
A FRAMMWORK FOR LINKING CULTURE AND IMPROVEMENT INITIATIVES IN ORGANIZATIONS
}

\author{
JAMES R. DETERT \\ Harvard University \\ ROGER G. SCHROEDER \\ JOHN J. MAURIEL \\ University of Minnesota
}

\begin{abstract}
We present $a$ synthesis of the general dimensions of organizational culture used most commonly in extant research and outline how these general dimensions correspond to the specific values and beliefs underlying total quality management (TQM) practice ( $\alpha$ comprehensive change initiative). We argue that the relationship between culture and implementation of new behaviors and practices has not been adequately explored because of the lack of a comprehensive framework for defining and measuring organizational cultures. Our framework presents a necessary step in moving toward culture as a useful explanatory concept in organizational research.
\end{abstract}

The one common denominator that led to failure in all of our previous quality efforts [prior to the mid 1980s] was that we did not change the culture or the environment in which all these tools and processes were being used. We had a "flavor of the month" mentality (Sam Malone, Worldwide Marketing Manager at Xerox Quality Solutions; quoted in Brennan, 1994: 36).

A company's prevailing cultural characteristics can inhibit or defeat a reengineering effort before it begins. For instance, if a company operates by consensus, its people will find the top-down nature of reengineering an affront to their sensibilities. Companies whose short-term orientations keep them exclusively focused on quarterly results may find it difficult to extend their vision to reengineering's longer horizons. Organizations with a bias against conflict may be uncomfortable challenging long-established rules. It is executive management's responsibility to anticipate and overcome such barriers (Hammer \& Champy, 1993: 207).

As illustrated above, the concept of culture continues to strike managers and managementoriented writers as a key variable in the success or failure of organizational innovations, such as quality improvement and reengineering. Yet, as

We gratefully acknowledge the support for this work provided by grants from the National Science Foundation and the Bush Foundation of Minnesota. the culture concept enters its third decade of active life in the field of organizational studies, debates about epistemology, levels and manifestations of the concept, and appropriate methodology have become "war games" that threaten the maturity of the concept beyond its preparadigmatic state (DiMaggio, 1997; Martin \& Frost, 1996; O'Reilly \& Chatman, 1996). Whatever theoretical position is taken-that cultures are "expressive symbols," "codes," "values and beliefs," "information and cognitive schemata"and whatever methods are used to investigate the phenomenon-"hermeneutics," "semiotics," "dramaturgy" (Barley, 1983; DiMaggio, 1997; Geertz, 1973; Goffman, 1959; Parsons \& Shils, 1990; Petersen, 1979) —we seem only to move farther away from a cumulative body of theory or empirical evidence that would benefit practitioners and theorists alike. There has been little effort to synthesize what dimensions of organizational culture have been studied to date or, more important, to identify which of these culture dimensions are most related to the implementation of change programs and subsequent improvements in important human and organizational outcomes. This lack of consolidation, followed by systemic empirical research, has led some to argue that interest in organizational 
culture as a driver of organizational innovation and performance is likely to fade unless this dearth of research is addressed (Firestone \& Louis, 1998; Pettigrew, 1990; Reichers \& Schneider, 1990; Smart \& St. John, 1996).

Here we begin to address this gap by making two contributions to discussions of organizational culture as it is related to the implementation of systemic improvement initiatives. First, we develop a framework of overarching, descriptive culture dimensions for use in studies of culture. Since the majority of these dimensions have been derived inductively through others' fieldwork, our belief was that a synthesis of what have repeatedly emerged as key components of culture would provide us with a hypothesis about which aspects of culture are most appropriate for future study. Second, to illustrate the utility of the framework, we link the general culture dimensions to a comprehensive set of values and beliefs that, we argue, represent the cultural backbone of successful total quality management (TQM) adoption. TQM provides a prominent case in point, where culture (with little systemic evidence about the specific elements of culture being referred to) has been labeled a key reason for the noninstitutionalization of new systems and behaviors (e.g., Becker, 1993; Hawley, 1995; Klein, Masi, \& Weidner, 1995; Masters, 1996; Olian \& Rynes, 1991; Rago, 1993; Westbrook, 1993).

The organization of this note flows from general to specific and descriptive to normative. In the next section we provide a brief overview of the cultural terms we use, including a discussion of definitions of culture and the levels and manifestations of culture. Following that, we review existing culture frameworks and organize them through qualitative content analysis into a set of eight overarching, descriptive dimensions of culture. As a concrete example, the normative, specific type of organizational culture called for by TQM is then outlined for each dimension. In the final section we describe a number of areas for future research and theory development.

\section{CULTURE LITERATURE}

Although the introduction of culture into the field of organizational theory generally is credited to Pettigrew in 1979, its presence in the social sciences-most notably, in sociology and anthropology-is ubiquitous and almost as old as the disciplines themselves (Pettigrew, 1979). This long history has seen a proliferation of definitions and conceptualizations of culture; in a 1952 review Kroeber and Kluckhohn cite over 150 definitions of culture from the literature.

Organizational researchers also have utilized a wide variety of culture definitions, although most empirical work has centered around the view of culture as an enduring, autonomous phenomenon that can be isolated for analysis and interorganization comparison (Alexander, 1990). ${ }^{1}$ These definitions have in common the view that culture consists of some combination of artifacts (also called practices, expressive symbols, or forms), values and beliefs, and underlying assumptions that organizational members share about appropriate behavior (Cooke \& Rousseau, 1988; Gordon \& DiTomaso, 1992; Rossman, Corbett, \& Firestone, 1988; Rousseau, 1990; Schall, 1983; Schein, 1992; Schwartz \& Davis, 1981). The idea that these shared conceptions act in a normative fashion to guide behavior has resulted in culture being called the "social glue" that binds the organization (Golden, 1992; Smircich, 1983). Although there is as yet no single, widely agreed upon conception or definition of culture, there is some consensus that organizational culture is holistic, historically determined, and socially constructed, and it involves beliefs and behavior, exists at a variety of levels, and manifests itself in a wide range of features of organizational life (Hofstede, Neuijen, Ohayv, \& Sanders, 1990; Pettigrew, 1990).

In empirical work a common approach has been to identify artifacts of a culture, such as the unique symbols, heroes, rites and rituals, myths, ceremonies, and sagas of an organization, and then to explore, to a greater or lesser extent, the deeper meanings of these artifacts (Deal \& Kennedy, 1982; Hofstede, 1991; Martin, 1992; Trice \& Beyer, 1984; Wuthnow \& Witten, 1988). Researchers of TQM and other systemic change initiatives also have traditionally concentrated

\footnotetext{
${ }^{1}$ Those with an alternative view of culture argue that culture is not something an organization "has" but, rather, is what the organization "is" (Hawkins, 1997; Meglino \& Ravlin, 1998; Riley, 1983; Smircich, 1983). According to those with this view, it is inappropriate to isolate variables for interorganization comparison. We believe the dimensions of culture presented in this note are appropriate descriptors of organizational culture in either case. This debate does not affect the ideas presented here and, as such, is left for another time.
} 
on the visible practices (artifacts) implemented. However, they have generally paid little direct attention to the values, beliefs, and underlying assumptions that support or impede these new behaviors. Therefore, in this note we focus on culture as "a system of shared values defining what is important, and norms, defining appropriate attitudes and behaviors, that guide members' attitudes and behaviors" (O'Reilly \& Chatman, 1996: 160). However, we draw upon emerging theory in which researchers assert that culture ultimately exists in the links among cognitions, human interactions, and tangible symbols or artifacts (DiMaggio, 1997). For example, one could argue that our general dimensions of culture mimic the cognitive schemata individuals use to organize their world, the shared TQM values represent more focused schemata created by interaction within an organization, and artifacts are the historical record of acted-upon cognitions. Thus, the cultural dimensions outlined in the next section can be studied in any or all of these forms by other researchers when developing or testing cultural theories or propositions.

\section{AN ORGANIZATIONAL CULTURE FRAMEWORK AND APPLICATION}

To identify the specific constructs or dimensions actually used by researchers to tap the larger concept of "organizational culture" over the past two decades, we performed a qualitative content analysis of the extant literature. The review took the form of first noting the overall conception of culture being presented in each paper or instrument and then organizing the specific dimensions of that conception into $a$ two-dimensional matrix with author(s) listed by row and dimensions listed by column. ${ }^{2}$ The matrix building began by our reviewing the first conception and listing each specific dimension of culture discussed in a separate column. Each subsequent conception was then entered rowwise, with the dimensions from that work en-

\footnotetext{
${ }^{2}$ Since our goal in this note was to develop a comprehensive, interrelated set of culture values/beliefs, we limited the review to those works presenting some type of overall framework or set of dimensions of organizational culture. A post hoc review of the litany of less comprehensive studies, however, suggests that our framework also includes those studies focusing on one or a small number of culture dimensions.
}

tered in the columns that contained similar ideas from the previously reviewed works. For example, our analysis began with a review of the conception presented by Schein (1992) in his well-known work, Organizational Culture and Leadership. The main ideas from Schein's work were entered into five columns, which included "nature of reality and truth" and "nature of time." The next conception reviewed, Hofstede et al. (1990), contained some ideas that could be placed in the columns created for Schein's work (i.e., we placed Hofstede's "need for security" value in the same column as Schein's "nature of human nature") and other ideas for which new columns had to be created (i.e., "process versus results oriented").

As the analysis proceeded, it became evident that a relatively small number of dimensions seemed to underlie the majority of existing culture concepts. In fact, when our review of over twenty-five multiconcept frameworks was complete, our matrix contained only thirteen columns. Upon review and discussion of the matrix, we judged four columns to be similar enough to others to be combined, and we eliminated one because it appeared only once. This left eight columns in the matrix, which we and three additional researchers then reviewed and discussed until a name for the dimension identified in each column had been jointly agreed upon. ${ }^{3}$

To apply our general culture dimensions framework to a specific initiative, we next scanned the TQM literature to determine what normative dimensions have been used to define the ideal culture of a TQM organization. In this search we identified basically two types of work. The first type includes studies in which researchers claim to be exploring TQM and its culture and yet deal almost exclusively in the realm of TQM practices. In a number of these studies, frameworks that implicitly or explicitly refer to only the practices (artifacts) that should be observed in a TQM organization are defined (i.e., Anderson, Rungtusanatham, \& Schroeder, 1994; Flynn, Sakakibara, \& Schroeder, 1994; Johnson, Anderson, \& Johnson, 1994; Marcoulides \&

\footnotetext{
${ }^{3}$ As Weick (1979) has noted, it is seldom possible in scientific endeavors to achieve accuracy, generality, and simplicity simultaneously in a single theory. Given the preparadigmatic state of culture research, we risked accuracy in order to provide a simple, generalizable framework that will guide attempts to build a cumulative knowledge base.
} 
Heck, 1993; Reynolds, 1986; Snyder \& AckerHocevar, 1995). Studies of this type are open to the criticism that they are tautological, since the quality values/beliefs listed often are not conceptually distinct from quality practices/artifacts; the implicit argument in these studies seems to be "organizations do practice $\mathrm{X}$ because their culture is to practice X."

The second type of studies identified is those in which researchers do focus exclusively on the measurement of values and beliefs and their relationship to TQM implementation. In these studies scholars use existing instruments or approaches for measuring culture, such as the Competing Values Framework (e.g., Cameron \& Freeman, 1991; Chang, 1996; Yeung, Brockbank, \& Ulrich, 1991; Zammuto \& Krakower, 1991) or the Organizational Culture Profile (e.g., Klein et al., 1995), and then discuss how various cultural profiles relate to TQM. Although these studies provide useful information about certain aspects of culture and their relation to TQM implementation, they are bound by the aspects of culture covered by the instrument and often do not demonstrate "a reasonable amount of correspondence between the values that are measured and the phenomena being investigated" (Meglino \& Ravlin, 1998: 359). For example, values and beliefs about the importance of customers and customer focus are undeniably a key aspect of TQM, yet these aspects of culture are not covered by the majority of culture instruments used to study TQM.

Given the limitations of these strands of research on TQM and culture, our approach was to explicitly focus on defining the cultural values underlying TQM and to link them to the general organizational culture dimensions we had identified. In doing so, we attempted to avoid the problems of tautology, incomplete coverage, and others that prevent one from saying that a comprehensive list of cultural values has been identified. In addition to the literature, we used the results from an expert panel of fifteen business executives and educators convened to discuss TQM values to hone our thinking. Using a modified nominal group technique, panel members were able to articulate any values they felt were critical to successful TQM implementation, as opposed to being limited to some predefined quality or culture framework (Van de Ven \& Delbecq,
1972). ${ }^{4}$ (More details on this panel are contained in the Appendix.)

As shown in Tables 1 and 2 and as discussed further below, our approach yielded a set of general organizational culture dimensions and specific TQM values for each of those dimensions. It is important to note that each of the normative TQM values articulated addresses some aspect of the general organizational culture dimension with which it is associated but does not cover the entire domain of the more general descriptive dimension. The same would be true if one used the general framework to identify the normative value system undergirding other systemic change programs, such as business process reengineering or organizational learning.

\section{Ideas About the Basis of Truth and Rationality in the Organization}

Within organizations people hold various ideas about what is real and not real and how what is true is ultimately discovered (Schein, 1992). For example, in educational organizations truth is often considered specialized and tacit, so teachers tend to gauge their effectiveness through personal experience and intuition or "gut feel" (Lortie, 1975). In other organizations truth is considered a product of systemic, scientific study. In these organizations hard data are considered vital for problem solving (Sashkin \& Kiser, 1993). Various conceptions of what is true and how that truth is determined may ultimately affect the degree to which people adopt either normative or pragmatic ideals (Hofstede et al., 1990).

TQM, for example, embraces an approach to truth and rationality represented by the scientific method and the use of data for decision making. This value is typically called "management by fact" and is a central value in the TQM literature (Flynn et al., 1994; Juran, 1988; National Institute of Standards and Technology [NIST], 1999; Saraph, Benson, \& Schroeder, 1989). The key idea is that any system based on cause and effect requires measurement and data to make improvements. Central to this criterion is the

\footnotetext{
${ }^{4}$ For example, the expert panel reported by Chang (1996) was restricted to a discussion of the items found in Quinn and Rohrbaugh's (1983) Competing Values Framework.
} 
TABLE 1

General Dimensions of Organizational Culture from the Literature

\section{Ideas Ábout:}

1. The basis of truth and rationality in the organization

2. The nature of time and time horizon

3. Motivation

4. Stability versus change/innovation/personal growth

5. Orientation to work, task, and coworkers

6. Isolation versus collaboration/cooperation

7. Control, coordination, and responsibility

8. Orientation and focus-internal and/or external
References

Beyer (1998); Dyer (1985); Gordon \& Cummins (1979); Halfhill, Betts, \& Hearnsberger (1989); Hofstede (1991); Reynolds (1986); Saphier \& King (1985); Sashkin (1996); Schein (1992); Tucker \& $\mathrm{McCoy}$ (1988)

Denison \& Mishra (1995); Halfhill, Betts, \& Hearnsberger (1989); Quinn \& Rohrbaugh (1983); Reynolds (1986); Sashkin \& Sashkin (1993); Schein (1992); Tucker \& McCoy (1988)

Beyer (1993); Dyer (1985); Hofstede (1991); Lorsch (1985); Reynolds (1986); Saphier \& King (1985); Sashkin \& Kiser (1991); Schein (1992); Tucker \& McCoy (1988)

Beyer (1998); Cooke \& Szumal (1993); Denison \& Mishra (1995); Gordon \& Cummins (1979); Halfhill, Betts, \& Hearnsberger (1989); Heck \& Marcoulides (1996); Hofstede (1991); Kilmann \& Saxton (1991); Leithwood \& Aitken (1995); Lortie (1975); Marcoulides \& Heck (1993); O'Reilly, Chatman, \& Caldwell (1991); Quinn \& Rohrbaugh (1983); Reynolds (1986); Saphier \& King (1985); Sashkin (1996); Snyder \& Acker-Hocevar (1995)

Cooke \& Szumal (1993); Hofstede (1991); Kilmann \& Saxton (1991); Leithwood \& Aitken (1995); O'Reilly, Chatman, \& Caldwell (1991); Quinn \& Rohrbaugh (1983); Reynolds (1986); Rokeach (1973); Saphier \& King (1985); Sashkin (1996); Schein (1992); Tucker \& McCoy (1988)

Denison \& Mishra (1995); Firestone \& Louis (1998); Halfhill, Betts, \& Hearnsberger (1989); Heck \& Marcoulides (1996); Hofstede (1991); Kilmann \& Saxton (1991); Leithwood \& Aitken (1995); Lortie (1975); O’Reilly, Chatman, \& Caldwell (1991); Quinn \& Rohrbaugh (1983); Reynolds (1986); Saphier \& King (1985); Saskin (1996); Saskin \& Kiser (1993); Schein (1992); Smart \& Hamm (1993); Tucker \& McCoy (1988)

Beyer (1998); Gordon \& Cummins (1979); Halfhill, Betts, \& Hearnsberger (1989); Heck \& Marcoulides (1996); Hofstede (1991); Kilmann \& Saxton (1991); Leithwood \& Aitken (1995); Leonard (1997); Quinn \& Rohrbaugh (1983); Reynolds (1986); Sashkin (1996); Sashkin \& Kiser (1993); Smart \& Hamm (1993)

Denison \& Mishra (1995); Dyer (1985); Halfhill, Betts, \& Hearnsberger (1989); Hofstede (1991); Leithwood \& Aitken (1995); Leonard (1997); Quinn \& Rohrbaugh (1983); Reynolds (1986); Sashkin (1996); Smart \& Hamm (1993); Tucker \& McCoy (1988) belief that trends, cause and effect, and interrelations among variables are too complex to be evident without such data collection and analysis.

\section{Ideas About the Nature of Time and Time Horizon}

Ideas about time underlie the orientation of many organizations. While Schein (1992) argues that this dimension includes how time is defined and measured, what kinds of time exist, and how important time is, others focusing on this dimension center primarily on the issue of time horizon. In particular, the time horizon of an organization helps determine whether leaders and other organizational members adopt longterm planning and goal setting or focus primarily on the here-and-now (Denison \& Mishra, 1995; Halfhill, Betts, \& Hearnsberger, 1989; Quinn \& Rohrbaugh, 1983; Quinn \& Spreitzer, 1991; Sashkin \& Sashkin, 1993; Tucker \& McCoy, 1988). Reynolds, for example, calls this difference in time horizon for goal setting "ad hockery versus planning" (Reynolds, 1986).

In the TQM literature there is a premium placed on long-term commitment, including the belief that short-term sacrifices might be neces- 
TABLE 2

A Proposed Model of TQM Values and Beliefs

(Values and Beliefs Essential to TQM-Overlaid onto Organizational Culture Dimensions)

Organizational Culture Dimension

1. The basis of truth and rationality in the organization

2. The nature of time and time horizon

3. Motivation

4. Stability versus change/innovation/personal growth

5. Orientation to work, task, and coworkers

6. Isolation versus collaboration/cooperation

7. Control, coordination, and responsibility

8. Orientation and focus-internal and/or external
TQM Value

Decision making should rely on factual information and the scientific method.

Improvement requires a long-term orientation and a strategic approach to management.

Quality problems are caused by poor systems-not the employees. Employees are intrinsically motivated to do quality work if the system supports their efforts.

Quality improvement is continuous and neverending. Quality can be improved with existing resources.

The main purpose of the organization is to achieve results that its stakeholders consider important. Results are achieved through internal process improvement, prevention of defects, and customer focus.

Cooperation and collaboration (internal and external) are necessary for a successful organization.

A shared vision and shared goals are necessary for organizational success. All employees should be involved in decision making and in supporting the shared vision.

An organization should be customer driven. Financial results will follow. sary to enhance quality in the long run (Anderson, Rungtusanatham, Schroeder, \& Devaraj, 1995; Dean \& Bowen, 1994; NIST, 1999). Furthermore, a long-term commitment includes the idea that organizations should make investments that support the long-range mission. For example, organizations should invest in learning programs and measurement systems that support and document progress on long-range goals. Thus, with TQM, the nature of time and time horizon is viewed in the direction of a long-term orientation, including strategic management of the organization.

\section{Ideas About Motivation}

Beliefs about what motivates humans are fundamental to the study of organizational behavior (Locke, 1978; Maslow, 1943; Vroom, 1964) and, therefore, not surprisingly, also appear frequently in conceptions of organizational culture. The concept of motivation is a central idea about the very nature of what it means to be human (Beyer, 1998; Schein, 1992). It encompasses ideas about whether people are motivated from within or by external forces, whether people are inherently good or bad (e.g., Dyer, 1985), whether people should be rewarded or punished, and whether effort or output can be changed by manipulating others' motivation.

In the TQM literature the belief is that most people are intrinsically motivated to do a good job but are often thwarted by the system in which they work (Amundson, Flynn, Rungtusanathan, \& Schroeder, 1997; Dean \& Bowen, 1994; Hackman \& Wageman, 1995; Saraph et al., 1989). For example, poor systems can lead to misunderstandings about what is required and provide erroneous information upon which to act. As a result, errors that appear to be due to human effort actually are due to systems that are inadequate in the first place. The TQM value, therefore, is that the source(s) of problems should be searched for in processes-not employees. According to this view, employees will be intrinsically motivated to do a good job if they work in an environment without fear and coercion; they will likewise be demotivated by extrinsic rewards stemming from the performance of processes and systems they do not control (Deming, 1986).

\section{Ideas Ábout Stability versus Change/Innovation/Personal Growth}

Closely tied to ideas about what motivates humans are ideas about humans' desire for sta- 
bility versus change. In some form this dimension is common to almost every culture framework reviewed. Several key concepts emerge within this dimension. First are ideas about change. Individuals, it is argued, have propensities toward stability or change (Cooke \& Szumal, 1993; Leithwood \& Aitken, 1995; Lortie, 1975; Reynolds, 1986). Some individuals are open to change, whereas others are said to have a high "need for security" (Hofstede et al., 1990). Individuals open to change are often referred to as risk takers (Leithwood \& Aitken, 1995; Reynolds, 1986). When organizations as a whole try to promote risk taking, conceptions of "organizational innovation" take center stage (Denison \& Mishra, 1995; Gordon \& Cummins, 1979; Halfhill et al., 1989; Heck \& Marcoulides, 1996; Marcoulides \& Heck, 1993; O’Reilly et al., 1991; Quinn \& Rohrbaugh, 1983; Reynolds, 1986; Toole, 1996). In innovative organizations there is often a push for constant, continuous improvement and an institutionalized belief that "we can always do better" (Sashkin, 1993; Sashkin \& Kiser, 1993). In risk-averse organizations the focus is on "not rocking the boat," and conceptions about doing or being "good enough" abound.

In the TQM literature there is a premium placed on change (as opposed to stability). This value, which is usually referred to as continuous improvement in the literature, is one of the fundamental dimensions of the TQM philosophy (Anderson et al., 1994; Dean \& Bowen, 1994; Deming, 1986; NIST, 1999; Saraph et al., 1989). It represents a mindset in which things are never viewed as "good enough" and is found in organizations in which processes and products are continuously studied for improvement. Included in this belief is the idea that improvements cannot come without change, so change should be viewed positively rather than feorfully.

A specific dimension of the continuous improvement mentality called for in TQM is the belief that quality can be improved without adding additional resources to a system. Instead, improvements can be achieved by improving internal processes, focusing on customers' needs, and preventing quality problems from occurring in the first place (Crosby, 1979; Flynn et al., 1994; Juran, 1988). In a sense, this value is the lynchpin of the quality philosophy: quality, defined as meeting or exceeding the customers' requirements now and in the future, can be increased without additional resources.

\section{Ideas About Orientation to Work, Task, and Coworkers}

A number of the culture frameworks reviewed contain ideas about the centrality of work in human life and about the balance between work as a production activity and a social activity (Hofstede et al., 1990; Schein, 1992). Some individuals view work as an end in itself. For these people, work has a "task focus," and the fundamental concern is on work accomplishment and productivity (O'Reilly et al., 199l; Reynolds, 1986). Other individuals see work primarily as a means to other ends, such as "a comfortable life" (Rokeach, 1973). For these individuals, productivity is a less important goal than the social relationships formed at work (Kilmann \& Saxton, 1991; Reynolds, 1986).

In the recent TQM literature, scholars take the position that the purpose of the organization is to achieve results that it and its stakeholders (customers, stockholders, employees, and community) consider important. For example, the Baldrige Criteria accord 45 percent of the total points to results including customer satisfaction, financial and market results, human resource results, and supplier and partner results (NIST, 1999). In the earlier quality literature, scholars did not hold this same view. Deming's philosophy (1986), for example, eschews a results focus in favor of a process focus. Deming thought organizations should focus on process improvement only and that by doing so results would follow. In the more recent literature, however, it is advocated that TQM values should focus on both process improvement and results.

\section{Ideas About Isolation versus Collaboration/ Cooperation}

Ideas about working alone or collaboratively occur in almost every framework reviewed. These ideas contain underlying beliefs about the nature of human relationships and about how work is most effectively and efficiently accomplished (Denison \& Mishra, 1995; Schein, 1992; Tucker \& McCoy, 1988). In some organizations almost all work is accomplished by individuals (e.g., Leithwood \& Aitken, 1995; Lortie, 1975). In these organizations working together is 
either viewed as inefficient or a violation of individual autonomy. In contrast, some organizations place a premium on collaboration as a means to better decisions and overall output. These organizations are likely to foster teamwork and organize tasks around groups of people rather than individuals (Denison \& Mishra, 1995; Kilmann \& Saxton, 1991; Quinn \& Rohrbaugh, 1983; Reynolds, 1986; Sashkin \& Kiser, 1993; Tucker \& McCoy, 1988).

TQM explicitly focuses on the importance of cooperation instead of isolation for achieving maximum effectiveness. Specifically, this value is centered on the belief that collaboration leads to better decisions, higher quality, and higher morale. The Baldrige Criteria refer to both internal and external partnerships as things an organization should value (NIST; 1999). In most TQM articles researchers represent this value as taking form through partnerships with suppliers and customers or through internal cooperation within the organization (i.e., Anderson et al., 1995; Flynn et al., 1994; Hackman \& Wageman, 1995; Saraph et al., 1989). These ideas are based on the belief that the organization will benefit from cooperation in the pursuit of quality.

\section{Ideas Ábout Control, Coordination, and Responsibility}

Like several other dimensions noted herein, ideas about control, coordination, and responsibility pervade almost all frameworks of organizational culture. Organizations vary in the degree to which control is concentrated (usually at the top) or shared (Beyer, 1998; Hofstede et al., 1990; Quinn \& Rohrbaugh, 1983). Where control is concentrated or "tight," there are formalized rules and procedures set by a few, which are intended to guide the behavior of the majority (Smart \& Hamm, 1993; Smart \& St. John, 1996). In tight control environments decision making is centralized (Reynolds, 1986). In organizations in which work is loosely controlled, flexibility and autonomy of workers are cherished. In loosely controlled organizations there are fewer rules and formal procedures, and power and decision making are shared throughout the organization (Heck \& Marcoulides, 1996; Leonard, 1997; Reynolds, 1986). Loose versus tight control cultures will have different needs for, and challenges in, coordinating the work of various individuals, groups, and areas (Beyer, 1998; Denison \& Mishra, 1995; Gordon \& Cummins, 1979; Hofstede et al., 1990; Sashkin, 1996).

In TQM these ideas take form through the view that a shared vision and shared goals among employees and management are critical for organizational success (Anderson et al., 1995; Deming, 1986; Hackman \& Wageman, 1995). This value refers to a belief in the power of coordinated action. According to this value, individuals should be willing to sacrifice some autonomy for the sake of organization-wide goals, because doing so will lead to superior outcomes. A shared vision and shared goals require that all staff members know and understand the organization's vision and are willing to align their actions accordingly. Consistent with the TQM view on collaboration, this value includes the idea that employees should be involved in meaningful ways in the decision making about the vision and goals they are asked to support (Dean \& Bowen, 1994; Saraph et al., 1989).

\section{Ideas About Orientation and Focus-Internal and/or External}

In many frameworks researchers consider the nature of the relationship between an organization and its environment a key aspect of culture. This relationship includes ideas about whether the organization assumes it controls, or is controlled by, its external environment (Dyer, 1985). The relationship also includes the fundamental orientation of the organization: internal, external, or both (Quinn \& Rohrbaugh, 1983; Reynolds, 1986; Smart \& Hamm, 1993; Smart \& St. John, 1996). Some organizations, it seems, assume that the key to organizational success is to focus on people and processes within the organization. For example, innovation within internally focused organizations is based primarily on what engineers, managers, scientists, and so forth believe to be an improvement over existing products, processes, or programs. In these organizations it is assumed that these internal experts are the ones who would know what an improvement over existing conditions would look like. Some organizations, however, are focused primarily on external constituents, customers, competitors, and the environment (Denison \& Mishra, 1995; Halfhill et al., 1989). For these organizations, innovation is based on what external stakeholders want, and improvements are 
judged by external benchmarks. Furthermore, these organizations search actively for new ideas and/or leadership from outside their traditional bounds.

An externally oriented view is consistent with TQM philosophies referring to TQM organizations as being customer driven and actively engaged in partnerships with the community, suppliers, and other external constituents (Dean \& Bowen, 1994; Flynn et al., 1994; Hackman \& Wageman, 1995; Juran, 1988; NIST, 1999; Saraph et al., 1989). Furthermore, employees in a TQM organization would believe that they should look to external sources for new information and that their success ought to be judged against external benchmarks.

\section{Summary}

In this section we have reviewed the eight dimensions that we derived to synthesize the substantive content of a sample of extant organizational culture work and have illustrated how these general dimensions relate to the "ideal culture" for a specific improvement initiative (TQM). In the next section we present some implications for organization theory and future research.

\section{IMPLICATIONS FOR ORGANIZATION THEORY AND FUTURE RESEARCH}

Contingency theorists predict that not all values in the general culture framework will be of equal importance in the implementation of various innovations (Lawrence \& Lorch, 1967; Thompson, 1967). For example, in contrast to the TQM culture articulated above, we anticipate that programs such as organizational learning (OL) and reengineering will have their own "idealtype" cultures derived from some or all of the general dimensions. Specifically, to support OL, an organization would need a culture that valued collaboration (because, without such, individual learning would not be translated into organizational learning), shared decision influence, and fact-based decision making (Fiol \& Lyles, 1985; Schön, 1983; Weick \& Westley, 1996).

Furthermore, contingency theory indicates that not all elements of culture particular to a specific innovation will need to be adopted to the same degree throughout the organization. In manufacturing environments, for example, it is hypothesized that quality culture elements like fact-based decision making will be most important on the production floor, whereas customer focus will be most critical for engineering and sales personnel. Thus, future research is needed to identify the cultural configurations of successful adoption of specific innovations, including the internal patterning of these cultures.

The importance of subcultures also should receive more research in the future. Previous research indicates that most culture change efforts proceed with little attention to the pluralistic reality of most modern organizations. For example, in case after case, senior executives have paid scant attention to the values and beliefs of lower-level employees, acting as if their management subculture represents a unitary, organization-wide culture (Martin, 1992; Sproull \& Hofmeister, 1986). Particular emphasis is needed on the interplay between enhancing subcultures (those that particularly embrace the new initiative) and countercultures (those that actively oppose it) in order to understand why some cultural conflicts end with real changes and others with a return to the status quo (Martin \& Siehl, 1983; Schein, 1996). Feminist and critical theory approaches, with their focus on those with less power and status, seem well suited for this task (Alvesson \& Deetz, 1996; Calás \& Smircich, 1996; Forester, 1983; Martin, 1992).

Finally, we suggest that future research and theory developments should be aimed at understanding the gaps between the culture that is espoused by certain organizational members and the one that actually describes the artifacts and behaviors visible throughout the organization. When these gaps are large, we believe that a change initiative such as TQM will be very difficult to implement. The general notion that "fit" (i.e., lack of culture gaps) is an important predictor of organizational outcomes is not new. Nadler and Tushman have suggested that various fits, such as between individual and task, between task and the organization, and between formal and informal organization, are all potentially useful explanations of microlevel and macrolevel behaviors and outcomes (Nadler \& Tushman, 1980a,b). In recent years fit research has been extended to the area of value congruence, which seems to us to be a promising approach for the study of culture and its impact on change initiatives. 


\section{CONCLUSION}

In this note we have attempted to address the current ambiguity about the concept of culture and its relationship to systemic improvement initiatives. We have done so by thoroughly reviewing and synthesizing the organizational culture literature, by presenting an application of the resultant culture dimensions framework to the TQM paradigm, and by suggesting directions for future research. We believe the general dimensions presented in Table 1 form a solid base for other researchers to use in framing future theoretical and empirical research on organizational culture. Ultimately, cumulative empirical research, based on a solid theoretical framework, is the only way to bring valid evidence to bear on the question of how organizational culture supports or inhibits systemic change implementation. We hope others will join in this quest to replace anecdotes, intuition, and vague statements about the importance of culture with more formal theory and empirical evidence.

\section{APPENDIX \\ AN EXPERT PANEL FOR ARTICULATING QUALITY VALUES}

In December 1997 a panel of fifteen distinguished educators and businesspersons convened to discuss the cultural values underlying TQM implementation. All participants have been intimately involved with TQM either as practitioners, consultants, or researchers. Several have served or currently are serving as state or national judges for Baldrige-based quality awards.

Prior to the meeting, each participant was sent $a$ one-page introduction to the group task. The introduction outlined our working definition of culture and the multiple levels at which culture can be defined. Several examples were given to show participants how quality-related culture can be expressed at the artifact (or practice) level and the value (or basic assumption) level. Participants were then asked to write as many quality-related values and artifacts as they could think of on the Post-it ${ }^{\circledR}$ notes provided and bring them to the meeting.

The meeting began with an overview of the task and an introduction to the steps of the mod- ified nominal group technique (NGT) that would be employed to elicit the cultural values of TQM. Participants were informed that the NGT is a research process used to "enrich the researchers' understanding of a problem by providing judgmental statements amenable to quantification" (Van de Ven \& Delbecq, 1972: 338). In this case the "problem" to be better understood was the cultural values underlying the theory of TQM. The NGT focused the group on the discussion and clarification of the quality-related artifacts and values they recorded before attending the panel meeting.

The NGT process began with each panel participant taking a turn reading to the group three or four of their prepared value and artifact statements (see examples below). Three members of the research team then placed each Post-it ${ }^{\circledR}$ on the large white board behind them. They then attempted to group the Post-it ${ }^{\circledR}$ notes into categories of similar value statements. After each participant had been given a chance to post their first three or four statements, the process was repeated until all participants had placed all their notes on the board. No discussion or evaluation of the value statements was made during this time, although participants were encouraged to "hitch-hike" on other people's ideas by presenting related but new ideas when their turn came (Van de Ven \& Delbecq, 1972).

\section{Examples of the Panel's Articulation of Value Statements and Artifacts}

\begin{tabular}{|c|c|c|}
\hline Value Name & Value & Artifact \\
\hline Long-run vision & $\begin{array}{l}\text { A strong } \\
\text { organization } \\
\text { needs/takes a } \\
\text { long-range view } \\
\text { of the future. }\end{array}$ & $\begin{array}{l}\text { Strategic } \\
\text { planning is } \\
\text { evident; } \\
\text { stakeholders } \\
\text { are involved } \\
\text { in the } \\
\text { planning. }\end{array}$ \\
\hline $\begin{array}{l}\text { Systems } \\
\text { approach/ } \\
\text { thinking }\end{array}$ & $\begin{array}{l}\text { Organizational } \\
\text { alignment is } \\
\text { critical for high } \\
\text { performance. }\end{array}$ & $\begin{array}{l}\text { Employees } \\
\text { understand } \\
\text { the } \\
\text { organization's } \\
\text { mission and } \\
\text { how their } \\
\text { position } \\
\text { relates to and } \\
\text { contributes to } \\
\text { reaching the } \\
\text { organization's } \\
\text { goals. }\end{array}$ \\
\hline
\end{tabular}




\begin{tabular}{|c|c|c|}
\hline Value Name & Value & Artifact \\
\hline $\begin{array}{l}\text { Continuous } \\
\text { improvement }\end{array}$ & $\begin{array}{l}\text { Improvement and } \\
\text { innovation are } \\
\text { important. }\end{array}$ & $\begin{array}{l}\text { Methods such as } \\
\text { suggestion } \\
\text { boxes are } \\
\text { evident. }\end{array}$ \\
\hline Customer focus & $\begin{array}{l}\text { Customers, } \\
\text { internal and } \\
\text { external, } \\
\text { deserve timely } \\
\text { and flexible } \\
\text { responses. }\end{array}$ & $\begin{array}{l}\text { Systems are in } \\
\text { place, such as } \\
\text { customer } \\
\text { comment cards, } \\
\text { to provide } \\
\text { customers } \\
\text { access to giving } \\
\text { feedback, and } \\
\text { they are } \\
\text { responded to in } \\
\text { a timely } \\
\text { manner. }\end{array}$ \\
\hline
\end{tabular}

During a break, the three researchers and one participant gave a tentative one- or two-word name to each of the categories created on the white board. Following the break, the categories were systemically discussed as the participants worked toward agreement on a one-sentence working definition for each of the categories. Seventeen one-sentence definitions were recorded on the wall in view of all participants (see examples below).

\section{TQM Value Names and Definitions Ās Defined by the Expert Panel}

\begin{tabular}{lc}
\hline Value Name & Value Definition \\
\hline Time/results/agility & $\begin{array}{c}\text { Prioritizing the use of time } \\
\text { leads to better results. } \\
\text { Long-run vision should drive } \\
\text { short-run actions. } \\
\text { All work should be viewed, } \\
\text { understood, and documented } \\
\text { Process }\end{array}$ \\
Ths a process. \\
The organization is an \\
interconnected set of \\
processes.
\end{tabular}

Although the original plan was to conclude the panel process with a vote to determine which of the values were considered most important to TQM implementation, the participants and research team agreed that little additional information would come from a formal vote; the group felt that all of the value state- ments were important to TQM. Furthermore, as a systemic approach, the group felt it would be inappropriate to suggest some TQM values might be important and others not. Thus, this traditional final step in the NGT was not conducted.

\section{REFERENCES}

Alexander, J. C. 1990. Analytic debates: Understanding the relative autonomy of culture. In J. C. Alexander \& S. Seidman (Eds.), Culture and society: Contemporary debates: 1-27. Cambridge: Cambridge University Press.

Alvesson, M., \& Deetz, S. 1996. Critical theory and postmodernism approaches to organizational studies. In S. R. Clegg, C. Hardy, \& W. R. Nord (Eds.), Handbook of organization studies: 191-217. Thousand Oaks, CA: Sage.

Amundson, S., Flynn, B., Rungtusanatham, A., \& Schroeder, R. 1997. The relationship between quality management values and national and organizational culture. Working paper, University of Minnesota, Minneapolis.

Anderson, J. C., Rungtusanatham, M., \& Schroeder, R. G. 1994. A theory of quality management underlying the Deming management method. Academy of Management Review, 19: 472-509.

Anderson, J., Rungtusanatham, M., Schroeder, R., \& Devaraj, S. 1995. A path analytic model of a theory of quality management underlying the Deming management method: Preliminary empirical findings. Decision Sciences, 26: 637-658.

$\rightarrow$ Barley, S. R. 1983. Semiotics and the study of occupational and organizational cultures. Administrative Science Quarterly, 28: 393-413.

Becker, S. W. 1993. TQM does work: Ten reasons why misguided attempts fail. Management Review, May: 30-33.

Beyer, J. 1998. Culture and TQM. Keynote address presented at the Quality and Management Conference, Arizona State University, Tempe.

Brennan, N. E. 1994. Lessons taught by Baldrige winners. New York: Conference Board.

Calós, M. B., \& Smircich, L. 1996. From "the woman's" point of view: Feminist approaches to organization studies. In S. R. Clegg, C. Hardy, \& W. R. Nord (Eds.), Handbook of organization studies: 218-257. Thousand Oaks, CA: Sage.

Cameron, K. S., \& Freeman, S. J. 1991. Cultural congruence, strength, and type: Relationships to effectiveness. Research in Organizational Change and Development, 5: 23-58.

Chang, S. L. 1996. Organizational culture and total quality management. Unpublished doctoral dissertation, University of Missouri at Rolla.

Cooke, R., \& Rousseau, D. 1988. Behavioral norms and expectations: $\AA$ quantitative approach to the assessment of organizational culture. Group and Organizational Studies, 13: 245-273. 
Cooke, R. A., \& Szumal, J. L. 1993. Measuring normative beliefs and shared behavioral expectations in organizations: The reliability and validity of the organizational culture inventory. Psychological Reports, 72: 1299-1330.

Crosby, P. 1979. Quality is free. New York: McGraw-Hill.

Deal, T., \& Kennedy, А. А. 1982. Corporate culture: Rites and rituals of organizational life. Reading, MA: AddisonWesley.

$\rightarrow$ Dean, J. W., Jr., \& Bowen, D. E. 1994. Management theory and total quality: Improving research and practice through theory development. Academy of Management Review, 19: 392-418.

Deming, W. E. 1986. Out of the crisis. Cambridge, MA: MIT Center for Advanced Engineering Study.

$\rightarrow$ Denison, D., \& Mishra, A. 1995. Toward a theory of organizational culture and effectiveness. Organization Science, 6: 204-224.

$\rightarrow$ DiMaggio, P. 1997. Culture and cognition. Annual Review of Sociology, 23: 263-287.

Dyer, W. G., Jr. 1985. The cycle of cultural evolution in organizations. In R. H. Kilmann, M. J. Saxton, \& R. Serpa (Eds.), Gaining control of the corporate culture: 200-229. San Francisco: Jossey-Bass.

$\rightarrow$ Fiol, C. M., \& Lyles, M. A. 1985. Organizational learning. Academy of Management Review, 10: 803-813.

Firestone, W. A., \& Louis, K. S. 1998. Schools as cultures. In J. Murphy \& K. S. Louis (Eds.), Handbook of research on educational administration (2nd ed.): 297-322. San Francisco: Jossey-Bass.

Flynn, B. B., Sakakibara, S., \& Schroeder, R. G. 1994. A framework for quality management research and an associated measurement instrument. Journal of Operations Management, 11: 339-366.

Forester, J. 1983. Critical theory and organizational analysis. In G. Morgan (Ed.), Beyond method: Strategies for social research: 234-246. Newbury Park, CA: Sage.

Geertz, C. 1973. The interpretation of cultures. New York: Basic Books.

Goffman, E. 1959. The presentation of self in everyday life. Garden City, NY: Doubleday-Anchor.

Golden, K. А. 1992. The individual and organizational culture: Strategies for action in highly-ordered contexts. Journal of Management Studies, 29: 1-21.

Gordon, G. G., \& Cummins, W. 1979. Managing management climate. Lexington, MA: Lexington Books.

Gordon, G. G., \& DiTomaso, N. 1992. Predicting corporate performance from organizational culture. Journal of Management Studies, 29: 783-798.

$\rightarrow$ Hackman, J. R., \& Wageman, R. 1995. Total quality management: Empirical, conceptual, and practical issues. Administrative Science Quarterly, 40: 309-342.

Halfhill, S. M., Betts, C. A., \& Hearnsberger, K. 1989. Development and validation of the BHOCS organizational culture survey. Unpublished manuscript.

Hammer, M., \& Champy, J. 1993. Reengineering the corpora- tion: A manifesto for business revolution. London: Harper Collins.

Hawkins, P. 1997. Organizational culture: Sailing between evangelism and complexity. Human Relations, 50: 417440.

Hawley, J. K. 1995. Where's the Q in TQM? Quality Progress, October: 63-64.

Heck, R. H., \& Marcoulides, G. A. 1996. School culture and performance: Testing the invariance of an organizational model. School Effectiveness and School Improvement, 7(1): 76-95.

Hofstede, G. 1991. Culture and organizations: Software of the mind. London: McGraw-Hill.

$\rightarrow$ Hofstede, G., Neuijen, B., Ohayv, D. D., \& Sanders, G. 1990. Measuring organizational cultures: $A$ qualitative and quantitative study across twenty cases. Administrative Science Quarterly, 35: 286-316.

Johnson, W. L., Anderson, R. H., \& Johnson, A. M. 1994. Assessing school work culture: An analysis and strategy. Paper presented at the annual meeting of the American Educational Research Association, New Orleans.

Juran, J. M. 1988. Juran on planning for quality. New York: Free Press.

Kilmann, R. H., \& Saxton, M. J. 1991. Kilmann-Saxton culturegap survey. Tuxedo, NY: Organizational Design Consultants.

Kilmann, R. H., Saxton, M. J., \& Serpa, R. (Eds.). Gaining control of the corporate culture. San Francisco: JosseyBass.

Klein, A. S., Masi, R. J., \& Weidner, C. K., II. 1995. Organization culture, distribution, and amount of control, and perceptions of quality. Group and Organization Management, 20: $122-148$.

Kroeber, A. L., \& Kluckhohn, C. 1952. Culture: A critical review of concepts and definitions. New York: Vintage Books.

Lawrence, P., \& Lorsch, J. 1967. Organization and environment. Boston: Harvard University Press.

Leithwood, K., \& Aitken, R. 1995. Making schools smarter: A system for monitoring school and district progress. Thousand Oaks, CA: Corwin Press (Sage).

Leonard, P. E. 1997. Understanding the dimensions of school culture. Paper presented at the annual meeting of the American Educational Research Association, Chicago.

Locke, E. A. 1978. The ubiquity of the technique of goal setting in theories of and approaches to employee motivation. Academy of Management Review, 3: 594-601.

Lorsch, J. W. 1985. Strategic myopia: Culture as an invisible barrier to change. In R. H. Kilmann, M. J. Saxton, \& R. Serpa (Eds.), Gaining control of the corporate culture: 84-102. San Francisco: Jossey-Bass.

Lortie, D. C. 1975. Schoolteacher: A sociological study. Chicago: University of Chicago Press.

Marcoulides, G. A., \& Heck, R. H. 1993. Organizational culture and performance: Proposing and testing a model. Organizational Science, 4: 209-225. 
Martin, J. 1992. Cultures in organizations: Three perspectives. New York: Oxford University Press.

Martin, J., \& Frost, P. 1996. The organizational culture war games: $\AA$ struggle for intellectual dominance. In S. R. Clegg, C. Hardy, \& W. R. Nord (Eds.), Handbook of organization studies: 599-621. Thousand Oaks, CA: Sage.

Martin, J., \& Siehl, C. 1983. Organizational culture and counter culture: An uneasy symbiosis. Organizational Dynamics, 12(2): 52-64.

$\rightarrow$ Maslow, A. H. 1943. A theory of human motivation. Psychological Review, 50: 370-396.

Masters, R. J. 1996. Overcoming the barriers to TQM's success. Quality Progress, 29(5): 53-55.

Meglino, B. M., \& Ravlin, E. C. 1998. Individual values in organizations: Concepts, controversies, and research. Journal of Management, 24: 351-389.

Nadler, D. A., \& Tushman, M. L. 1980a. A congruence model for organizational assessment. In E. E. Lawler, III, D. A. Nadler, \& C. Cammann (Eds.), Organizational assessment: Perspectives on the measurement of organizational behavior and the quality of work life: 261-278. New York: Wiley.

Nadler, D. A., \& Tushman, M. L. 1980b. A model for diagnosing organizational behavior. Organizational Dynamics, 9(2): 35-51.

National Institute of Standards and Technology (NIST). 1999. Malcolm Baldrige National Quality Award 1998 Education Criteria for Performance Excellence. Washington, DC: Department of Commerce.

Olian, J. D., \& Rynes, S. L. 199l. Making total quality work. Human Resource Management, 30: 303-333.

O’Reilly, C. A., III, \& Chatman, J. A. 1996. Culture as social control: Corporations, cults, and commitment. In B. M. Staw \& L. L. Cummings (Eds.), Research in organizational behavior, vol. 18: 157-200. Greenwich, CT: JAI Press.

$\rightarrow$ O'Reilly, C. A., III, Chatman, J., \& Caldwell, D. F. 1991. People and organizational culture: $\AA$ profile comparison approach to assessing person-organization fit. Academy of Management Journal, 34: 487-516.

Parsons, T., \& Shils, E. 1990. Values and social systems. In J. C. Alexander \& S. Seidman (Eds.), Culture and society: Contemporary debates: 31-38. Cambridge: Cambridge University Press.

$\rightarrow$ Peterson, R. A. 1979. Revitalizing the cultural concept. Annual Review of Sociology, 5: 137-166.

$\rightarrow$ Pettigrew, A. M. 1979. On studying organizational cultures. Administrative Science Quarterly, 24: 570-581.

Pettigrew, A. M. 1990. Conclusion: Organizational climate and culture: Two constructs in search of a role. In B. Schneider (Ed.), Organizational climate and culture: 413-434. San Francisco: Jossey-Bass.

$\rightarrow$ Quinn, R. E., \& Rohrbaugh, J. 1983. A spatial model of effectiveness criteria: Towards a competing values approach to organizational analysis. Management Science, 29: 363-377.

Quinn, R. E., \& Spreitzer, G. M. 1991. The psychometrics of the competing values culture instrument and an analysis of the impact of organizational culture on quality of life. Research in Organizational Change and Development, 5: $115-142$.

Rago, W. 1993. Struggles in transformation: A study in TQM, leadership, and organizational culture in a government agency. Public Administration Review, 56(3): 227-234.

Reichers, A. E., \& Schneider, B. 1990. Climate and culture: An evolution of constructs. In B. Schneider (Ed.), Organizational climate and culture: 5-39. San Francisco: JosseyBass.

Reynolds, P. D. 1986. Organizational culture as related to industry, position, and performance: $\AA$ preliminary report. Journal of Management Studies, 23: 333-345.

Riley, P. 1983. A structurationist account of political culture. Administrative Science Quarterly, 28: 414-437.

Rokeach, M. 1973. The nature of human values. New York: Free Press.

Rossman, G. B., Corbett, H. D., \& Firestone, W. A. 1988. Change and effectiveness in schools: A cultural perspective. Albany: State University of New York Press.

Rousseau, D. M. 1990. Assessing organizational culture: The case for multiple methods. In B. Schneider (Ed.), Organizational climate and culture: 153-192. San Francisco: Jossey-Bass.

Saphier, J., \& King, M. 1985. Good seeds grow in strong cultures. Educational Leadership, 42(6): 67-74.

Saraph, J. V., Benson, P. G., \& Schroeder, R. G. 1989. Ån instrument for measuring the critical factors of quality management. Decision Sciences, 20: 810-829.

Sashkin, M. 1993. Total quality management assessment inventory: Trainer guide. Seabrook, MD: Ducochon Press.

Sashkin, M. 1996. Organizational beliefs questionnaire: Pillars of excellence (3rd ed.). Amherst, MA: Human Resource Development Press.

Sashkin, M., \& Kiser, K. J. 1993. Putting total quality management to work: What TQM means, how to use it, and how to sustain it over the long run. San Francisco: BerrettKoehler.

Sashkin, M., \& Sashkin, M. G. 1993. Principals and their school cultures: Understandings from quantitative and qualitative research. In M. Sashkin \& H. J. Walberg (Eds.), Educational leadership and school culture: 100123. Berkeley, CA: McCutchan.

$\rightarrow$ Schall, M. 1983. A communications-rules approach to organizational culture. Administrative Science Quarterly, 28: 557-581.

Schein, E. 1996. Culture: The missing concept in organization studies. Administrative Science Quarterly, 41: 229-240.

Schein, E. H. 1992. Organizational culture and leadership (2nd ed.). San Francisco: Jossey-Bass.

Schön, D. A. 1983. Organizational learning. In G. Morgan (Ed.), Beyond method: Strategies for social research: 114128. Newbury Park, CA: Sage.

Schwartz, H., \& Davis, S. M. 1981. Matching corporate culture 
and business strategy. Organizational Dynamics, 10(1): 30-38.

Smart, J. C., \& Hamm, R. E. 1993. Organizational culture and effectiveness in two-year colleges. Research in Higher Education, 34: 95-106.

$\rightarrow$ Smart, J. C., \& St. John, E. P. 1996. Organizational culture and effectiveness in higher education: $A$ test of the "culture type" and "strong culture" hypotheses. Educational Evaluation and Policy Analysis, 18: 219-241.

$\rightarrow$ Smircich, L. 1983. Concepts of culture and organizational analysis. Administrative Science Quarterly, 28: 339-358.

Snyder, K., \& Acker-Hocevar, M. 1995. Managing change to a quality philosophy: A partnership perspective. Paper presented at the annual international conference of the Association of Management, Vancouver, BC.

Sproull, L. S., \& Hofmeister, K. R. 1986. Thinking about implementation. Journal of Management, 12(1): 43-60.

Thompson, J. D. 1967. Organizations in action; social science bases of administrative theory. New York: McGraw-Hill.

Toole, J. 1996. Professional work life of teachers. Minneapolis: University of Minnesota Compass Institute.

$\rightarrow$ Trice, H. M., \& Beyer, J. M. 1984. Studying organizational cultures through rites and ceremonials. Academy of Management Review, 9: 653-669.

Tucker, R. W., \& McCoy, W. J. 1988. Can questionnaires mea- sure culture?: Eight extended field studies. Paper presented at the annual convention of the American Psychological Association, Atlanta.

Van de Ven, А. H., \& Delbecq, А. L. 1972. The nominal group as a research instrument for exploratory health studies. American Public Health Association Journal, March: 337342.

Vroom, V. H. 1964. Work and motivation. New York: Wiley.

Weick, K. E. 1979. The social psychology of organizing (2nd ed.). Reading, MA: Addison-Wesley.

Weick, K. E., \& Westley, F. 1996. Organizational learning: Affirming an oxymoron. In S. R. Clegg, C. Hardy, \& W. R. Nord (Eds.), Handbook of organization studies: 440-458. Thousand Oaks, CA: Sage.

Westbrook, J. D. 1993. Organizational culture and its relationship to TQM. Industrial Management, 35(1): 1-3.

Wuthnow, R., \& Witten, M. 1988. New directions in the study of culture. Annual Review of Sociology, 14: 49-67.

Yeung, A. K. O., Brockbank, J. W., \& Ulrich, D. O. 1991. Organizational culture and human resource practices: An empirical assessment. Research in Organizational Change and Development, 5: 59-81.

Zammuto, R. F., \& Krakower, J. Y. 1991. Quantitative and qualitative studies of organizational culture. Research in Organizational Change and Development, 5: 83-114.

James R. Detert is a doctoral candidate in organizational behavior at Harvard University. He was previously a researcher at the University of Minnesota, where he studied the impact of culture on TQM implementation in U.S. high schools. His research interests include organizational culture and institutions and their impact on change efforts.

Roger G. Schroeder holds the Donaldson Chair in Operations Management at the Carlson School of Management, University of Minnesota, and is the codirector of the Juran Center for Leadership in Quality. He has a Ph.D. from Northwestern University. His research interests are in the areas of school administration, quality management, and high-performance manufacturing.

John J. Mauriel is an associate professor at the Carlson School of Management, University of Minnesota, and director of the Bush Educators Program. He holds a DBA from Harvard University. His research interests are in the areas of quality management in schools and strategic change. 